\title{
Institutional Accountability of Non-state Actors in the UNFCCC: Exit, Voice, and Loyalty
}

\author{
Jonathan Kuyper, Karin Bäckstrand and Heike Schroeder
}

\begin{abstract}
How are nonstate actors within the United Nations Framework Convention on Climate Change (UNFCCC) held to account? In this article, we introduce the concept of "institutional accountability" to complement the wider literature(s) on accountability in climate governance. Within institutional frameworks, actors employ rules, norms, and procedures to demand justifications from one another. In light of those justifications, actors then use "exit, voice, or loyalty" to positively or negatively sanction each other. To depict the dynamics of institutional accountability, we analyze the role of nonstate actors in the nine constituency groups of the UNFCCC. We outline the constituency structure and the population of observer organizations. We then identify examples where nonstate actors employed institutional rules in tandem with exit, voice, or loyalty to foster accountability. In making this analysis we draw upon three years of on-site participation at UNFCCC meetings, document analysis, and more than 40 semistructured interviews with state and nonstate actors. We conclude by discussing the scope and conditions under which institutional accountability may occur in other issue areas of global governance.
\end{abstract}

\section{Introduction}

The 2015 Paris Conference of the Parties under the United Framework Convention on Climate Change (UNFCCC) heralded the arrival of a legally binding treaty to limit global temperature rises and deal with the impacts of climate change. Over the course of two weeks, ten thousand non-state actors descended on Le Bourget conference center to attend the negotiations alongside nearly thirty-five thousand state delegates. This group of non-state actors is formally divided into nine constituencies within the UNFCCC system including businesses, NGOs, trade unions, 
indigenous groups, and several more. Non-state actors attend these negotiations for many different reasons, such as influencing states, providing information, representing excluded groups, and acting as watchdogs. As non-state actors have become a permanent feature of UNFCCC negotiations, questions arise over to whom they are accountable. In this article, we focus on one under-researched aspect, namely how non-state actors hold one-another to account within the UNFCCC system.

This article develops and applies a conception of institutional accountability and thereby contributes to the already-established literature on the accountability of non-state actors in climate governance specifically and global governance more broadly (see respectively: Newell, 2008; Grant \& Keohane 2005). Accountability, as we use the term, has two components: first, some set of actors (accountability wielders) is able to demand justification from another (accountability holders) in accordance with established standards; and, second, in light of those justifications, confer positive or negative sanctions (Keohane, 2003). Generally speaking, three forms of accountability are discussed in the literature. First there is an 'internal' or 'delegation' dimension of accountability, whereby actors are accountable to those who empower them. Second there is an 'external' or 'participation' dimension of accountability in which agents are accountable to affected societal stakeholders outside their particular institution. Third are 'networked' forms of accountability in which interactions between network members gives rise to demands and mechanisms for monitoring and review of procedures.

To further develop the dynamics of non-state actor accountability, we argue that another dimension of accountability is required to understand how non-state actors are held to account within global governance institutions, such as the UNFCCC. We call this institutional accountability. ${ }^{1}$ Within institutional frameworks, rules, norms and procedures exist so that nonstate actors can demand justifications horizontally from one another. These same institutional frameworks also enable mechanisms for providing positive and negative sanctions. ${ }^{2}$ Drawing on the seminal work by Albert Hirschman (1970), we contend that actors can employ 'exit, voice, and loyalty' - withdrawing support, criticizing or praising performance, or remaining loyal - to

\footnotetext{
${ }^{1}$ We define institutions as formal clusters of rules, norms, and procedures governing relationships between those working within that institutional framework (Young, 2002, p. 5). Rules are specific prescriptions or proscriptions for action. Norms are standards of behavior for determining right and wrong. And procedures are prevailing practices for making and implementing collective choice. See Krasner (1982).

${ }^{2}$ Accountability is here treated as a means of curtailing the power of other actors, not as an end in itself. See Kramarz and Park (this issue).
} 
hold other actors to account. We emphasize how exit, voice, and loyalty can work in isolation as separate mechanisms to produce accountability, but we also explore the interactions between these mechanisms. This is particularly important because loyalty works essentially to modify the impact of both exit and voice. The model of institutional accountability we develop is distinct from internal and external variants because it rests on neither a principal-agent model or on a democratic model of affectedness. Moreover, it is different from network accountability because actors share a more formalized institutional space and may or may not have established networked patterns of interaction.

In order to empirically illustrate the dynamics of institutional accountability, we analyze the role of non-state actors in the UNFCCC system. We outline the constituency structure and the population of observer organizations. We then identify examples where non-state actors employ institutional rules, norms, or procedures in tandem with exit, voice, and loyalty to foster accountability within the UNFCCC negotiations. We hone in on the effects of these sanctions to highlight the importance of institutional accountability, and to focus on how accountability battles between non-state actors play out as part of broader power relations in the UNFCCC. ${ }^{3}$ Methodologically, this article offers an illustrative case study that elucidates how institutional accountability is employed within and between non-state actors in the UNFCCC. We argue that the UNFCCC is an interesting case to study because of its central importance in climate governance as well as its high degree of access, inclusion, and participation of non-state actors. ${ }^{4}$ We do not provide a comprehensive inventory of all interactions between non-state actors within the UNFCCC, but rather seek to highlight how institutional rules, norms, and procedures combine with exit, voice, and loyalty to create the specific mode of institutional accountability that we advance. In doing so we draw upon a raft of primary sources including UNFCCC documents, data from event observations, position papers from different constituency groups, and the websites of various NGOs to understand their governance structures and procedures. We also conducted more than 40 semi-structured interviews during the Bonn Intersessional in 2013, COP19 in Warsaw during 2013, COP20 in Lima during 2014, and the

\footnotetext{
${ }^{3}$ As such, the ways in which states may engage in 'institutional accountability' is bracketed from our analysis.

${ }^{4}$ These dual reasons of centrality and inclusivity provide reasons to think that the results of the case study may be generalizable to other institutions in different issue areas which also have high rates of access.
} 
Bonn Intersessional in 2015. The interviews cover non-state actors from each constituency group as well as officials from the UNFCCC Secretariat. ${ }^{5}$

The article moves forward in four stages. First, we discuss previous literature on the accountability of non-state actors in climate change governance and global governance. This helps differentiate and define the concept of institutional accountability. Second, we specify the role of non-state actors within the UNFCCC institutional system. Third, we investigate how institutional accountability arises within the UNFCCC. This entails looking at how rules, procedures, and norms are used to demand justification and, subsequently, how exit, voice, and loyalty are used to generate sanctions. This article is, to our knowledge, the first to link Hirschman's framework of exit, voice, and loyalty to wider analyses of accountability and empirically apply it to climate governance. Finally, we conclude by noting that institutional accountability is a crucial part of climate and global governance. We suggest that future research should seek to identify if, how, and under what conditions institutional accountability exists in other issue-areas of world politics (Kramarz and Park, this issue). ${ }^{6}$

\section{Accountability and Non-State Actors}

\section{Literature Overview}

At national, regional, and transnational levels of governance, questions about the importance of accountability have proliferated in recent decades (Keohane 2003; Gates and Hill, 1995). In this article we focus on accountability beyond the state (Grant \& Keohane, 2005), specifically within the broader landscape of climate governance (Friedman et al., 2005; Bäckstrand, 2008; Betsill et al., 2015). From Copenhagen to Paris, the focus has primarily been on accountability of states for their (lack of) compliance with emission targets. There has been attention on why states delegate responsibility to different international organizations (IOs), and how accountability is maintained

\footnotetext{
${ }^{5}$ See Appendix A. Interviewees are listed alphabetically. Full interview details, including interview protocol, are on file with authors.

${ }^{6}$ Our view of institutional accountability reflects clearly the 'means vs. ends' distinction of accountability used to frame this special issue: Norms, rules, and procedures - which often give rise to shared standards between accountability holders and wielders - provide the means of accountability; exit, voice, and loyalty as sanctioning mechanisms provide the ends of accountability (see also Kramarz and Park 2016).
} 
in these delegation chains (Green, 2014). Focusing on how states and international secretariats are held to account for achieving low-carbon development pathways as the world strives to reach an agreement to limit global warming remains an important topic not least after the adoption of the Paris Agreement in 2015. Also important here is the accountability of non-state actors (Newell, 2008; Balboa, this issue).

There are many reasons why the accountability of non-state actors matters. On one hand, it is increasingly recognized that these actors influence states through normative pressures (Betsill \& Corell, 2001, 2008). This can involve inside or outside lobbying, social movement tactics, coalition-building, and naming and shaming (Hadden, 2014; Derman, 2014). The exercise of influence by non-state actors fuel questions of accountability. On the other hand, nonstate actors are often seen (or even portray themselves) as critical agents who represent the public interest in multilateral affairs (Betsill \& Corell, 2008; Omelicheva, 2009; Nasiritousi et al., 2014; Balboa, this issue). Yet as Scholte (2004, pp. 230-231) concludes, one of the challenges for civil society in seeking to promote democratic accountability in global governance is their own lack of accountability: "some civil society players in global politics have not even met minimal standards of accountability". Although non-state actors are often constrained by the institutional rules of different IOs, international law, powerful states, and their fiscal donors, many other forms of accountability also exist that require uncovering and analysis.

In this vein, the literatures on climate governance and world politics offer three broad (though certainly not mutually exclusive) ways to conceive of the accountability of non-state actors. ${ }^{7}$ The first is often called an 'internal' or delegation model of accountability. This internal view of accountability follows a principal-agent model in which a principal delegates power to an agent and establishes rules and procedures to constrain and/or reward said agent. This is the model through which IOs are typically established and regulated, but also applies to non-state actors that are provided authority and/or funding by donors, states, or IOs (see Rosenberg, this issue). Non-state actors - such as industry groups, indigenous movements, NGOs, and so on can thus be granted power by their own members who pay dues or find other ways to provide a base of political support. Jessica Green (2014) has analyzed how accountability operates in the Clean Development Mechanism (CDM) under the Kyoto Protocol as private actors are

\footnotetext{
${ }^{7}$ These modes of accountability do not apply only to non-state actors but are often used to look at sub-state and national actors.
} 
accountable to the CDM Executive Board that delegate differentiated powers and can initiate reviews of specific cases of validation.

A second view of non-state actor accountability focuses on an 'external' dimension. In this, actors are held accountable to those societal actors they affect (for a detailed typology of internal and external accountability, see Grant \& Keohane, 2005, p. 31). This external condition is normatively laden, derived mainly from democratic theory, as it understands accountability as a relationship that should exist between those who wield power and those whose lives are affected or constrained by the exercise of power. In the literatures on global democracy, affectedness remains the cornerstone of how to link sites of global public power with the relevant democratic publics (Macdonald, 2008). Within the climate governance scholarship, Hayley Stevenson and John Dryzek (2014) draw upon this external model as a way to hold state and non-state actors to account and, subsequently, democratize climate governance (see also: Newell, 2008, p. 148; Johnson, this issue).

A third discussion revolves around networked forms of non-state actor accountability (Slaughter, 2004; Bäckstrand, 2008; Gerlak, 2015; Bomberg, 2012). In the international relations literature, Anne-Marie Slaughter (2004) documents how the rise of public and private networks such as those between securities regulators or central bankers - leads to disaggregated sovereignty. While wary of accountability deficits, Slaughter largely sees networked governance as creating preconditions for accountability through monitoring, deliberation, and peer review. The climate policy literature has also focused on the accountability of networked climate governance in private or hybrid forms as well as cities and municipal networks (Newell, 2008; Rosenthal et al., 2015). In loose and informal networks, accountability is manifest as agents agree to hold each other to similar standards, compete for funding and market space, or just generally leverage 'naming and shaming' tactics against one another. Bäckstrand (2008), for instance, uses these mechanisms to expose the strengths and weaknesses of accountability in public-private partnerships (such as the World Summit on Sustainable Development Climate Partnerships) or private networks (such as the International Climate Change Partnerships (ICCP)).

\section{Institutional Accountability}


We find all three types of accountability important as they reflect key aspects of accountability in global governance. ${ }^{8}$ Delegation, participation, and networks certainly provide avenues for some actors to demand justifications from others and seek recourse/consent for those actions.

However, we suggest that these three forms of accountability miss an important dimension, that non-state actors are - or can be - held to account by those with whom they share an institutional space or framework. This model does not follow the principal-agent logic as agents join institutions separately without a delegation chain; it does not entail that all affected parties are present within an institution; and the institutions can have different networks operating within the same framework. For instance, in the case discussed at length in this article, the UNFCCC constituency system provides the institutional space in which many different networks operate. This institutional space means that accountability demands arise within as well as between networks. Accordingly, we advance institutional accountability as a distinct mode of accountability that represents a gap in current literature.

To formalize the concept we argue that institutional accountability contains two key components in line with the above definition of accountability. First, institutional frameworks provide a shared terrain of rules, norms, and procedures which are employed by agents (accountability wielders) to demand justification from other members (accountability holders) of the institution. ${ }^{9}$ Second, within that institutional framework, mechanisms of exit, voice, and loyalty enable both positive and negative sanctioning of the accountability holder by the accountability wielder (Hirschman, 1970). Sanctioning here refers to the granting or removal of support and/or resources. We consider institutional accountability to have occurred when these two necessary and sufficient conditions are met: demands for justifications are raised and, in light of those justifications and shared standards, exit, voice, or loyalty is employed to create positive or negative sanctions.

It is important to hone in on what standards accountability wielders engage to judge justifications from accountability holders. We suggest that these standards are expectations about

\footnotetext{
${ }^{8}$ These three variants of accountability, along with the fourth variant of institutional accountability, are better viewed as ideal types. In reality, most governance systems blend types of each.

${ }^{9}$ In some instances rules, procedures, and norms provide mechanisms for sanctioning. In these instances, 'exit, voice, or loyalty' may not be necessary for accountability to occur (though exit, voice, or loyalty may be used to compound the effects of institutional rules, procedures, and norms). However, in instances where institutional rules, procedures, and norms do not allow for sanctioning, we argue that exit, voice or loyalty may be especially critical for generating accountability.
} 
how accountability wielders should act in light of their role in an institutional framework. This could include following formal and informal rules, norms, and procedures that bind them, but it could also entail normative expectations about their purpose in the institution they inhabit (we elucidate both in our empirics). For instance, in the case of the UNFCCC, the utility of working groups, the way morning meetings are run, and inter-constituency negotiations provide some of the rules, norms, and procedures employed by accountability wielders to demand justifications and act as the standards against which to judge accountability holders. At other times, though, different normative stances about the role of accountability holders in an institution are used. For example, the split between radical and mainstream NGOs described in this article reflects a different vision of how climate change should be tackled, what role civil society groups should play in negotiations, and what pathways to decarbonization are acceptable. Once justifications are demanded through rules, norms, and procedures - and judgments made in light of these standards - exit, voice, and loyalty is then used to leverage sanctioning. This framework of institutional accountability allows us to focus on how actors - in this case non-state actors engage in power battles to question and sanction one-another. ${ }^{10}$ These four ideal typical modes of accountability are presented here in Table 1.

\section{- Insert Table 1 here -}

Because we are introducing a new theoretical framework for understanding accountability, the ways that exit, voice, and loyalty can produce positive and negative sanctions are important to flesh out. Our account draws substantively upon, though differs in some key respects from, Hirschman's original theory. ${ }^{11}$ Predominantly, we argue that exit is used as a negative sanction, voice can be used for both negative and positive sanctioning, and loyalty is employed as a positive sanction that moderates the effects of both exit and voice. Exit is used as a way to remove support or resources from another agent. Exit comes in two forms within institutional accountability (Dowding et al., 2000). First, there is a type of 'qualified exit' in which actors leave part of an institution but simply relocate to another part of the institutional framework. The

\footnotetext{
${ }^{10}$ We therefore contend that accountability demands are a subset of power relationships. We thank a reviewer for encouraging us to clarify this relationship.

${ }^{11}$ Perhaps most notably, Hirschman's theory was about firm or organizational responses to lost support to regain market share. We here emphasize the how the same mechanisms can produce accountability.
} 
second is a form of 'complete exit' in which actors leave the entire institution to remove support and indicate their displeasure. This follows Hirschman's logic that exit is used by actors to show dissatisfaction and seek to punish an agent for insufficient goods or services provision (or, in this case, poor justification). Exit is likely when actors have less loyalty to the accountability holder and the successful usage of voice is deemed low (Hirschman, 1970, p. 83).

Voice can be used as a form of either positive or negative sanctioning by agents to show their approval or disapproval of others' justification. Voice can provide positive sanctions by accepting justifications, mobilizing others to support an agent, and providing social capital. Alternately, voice can be used to criticize justifications, mobilize others against a justifier, or demand more justifications causing the justifier to expend further resources and time. Two types of voice are worth differentiating here. The first is a form of 'vertical voice' in which approval or disapproval is directed toward the justifier. The second is a form of 'horizontal voice' in which an actor, after receiving a justification, voices either approval or disapproval to other actors inside or outside of the institutional framework. Again following Hirschman (1970, p. 76), the use of voice is more likely to generate accountability through negative or positive sanctions when the accountability holder knows that accountability holders have exit options.

Finally, loyalty is used to show support for a justification and thus provides a form of positive sanctioning. This mechanism intersects with - and helps qualify - the use of exit and voice. Accountability wielders who are satisfied that justifications are adequately provided will show support and remain loyal. Relatedly, accountability holders can seek to secure loyalty to make exit and negative voice less likely. ${ }^{12}$ Although we recognize that it is methodologically difficult to separate loyalty from inaction as both provide de facto support, it is important to make a theoretical separation (Barry, 1974). Equally, it is important to separate between 'loyalty to the justifier' and 'loyalty to the entire institutional framework' (i.e. a justification is rejected but an actor remains loyal to the institution due to a desire not to upset the institutional equilibrium). As such, it is critical to probe how, and to whom, loyalty is being granted in practice. We therefore acknowledge the importance of identifying both when loyalty differs from inaction and to whom loyalty is being granted (Dowding et al., 2000). We elucidate this in our

\footnotetext{
${ }^{12}$ In a formal sense, loyalty acts as elasticity that means that accountability holders have more ability to avoid justifications without facing negative sanctions. We thank a reviewer for bringing this connection to our attention.
} 
empirical analysis. Having now summarized the core tenets of institutional accountability, we turn toward explicating and analyzing the constituency groups within the UNFCCC.

\section{Non-state Actors in the UNFCCC and Beyond}

\section{UNFCCC and the Role of Non-State Actors}

The institutional framework analyzed in this article is the UNFCCC, which stands at the epicenter of the climate change regime after more than two decades of negotiations on climate change mitigation and adaption (Betsill et al., 2015). The 1997 Kyoto Protocol reaffirmed the notion that the UNFCCC was the central venue to negotiate GHG emission reductions. Moreover, the recent Paris Agreement adopted in December 2015 has consolidated the role of UNFCCC as a catalyzer and facilitator of non-state climate action on global climate governance (Hale 2016).

Over the past 15 or so years, though, the centralized nature of global climate governance has given way to a more fragmented and polycentric system (Jordan et al. 2015; Pattberg and Widerberg, forthcoming). The Copenhagen Accord also paved the way for a decentralized system of bottom-up pledges for carbon emission reductions replacing quantified targets and timetables in the Kyoto Protocol. The system of voluntary pledge-making by states has been formalized in the outcomes in subsequent summits, such as the decisions on intended nationally determined contributions in the Lima Call for Climate Action. Although the UNFCCC remains a key part of the regime complex for climate change, especially in light of the Paris Agreement, previous deadlock in multilateral climate negotiations sparked interest in new modes of public, private, and hybrid transnational climate governance (Betsill et al. 2015; Bäckstrand, 2008). This led to recognition of the growing number and importance of non-state actors in climate change governance.

Although there has been an explosion of non-state actor activity outside the UNFCCC (Fisher and Galli 2015), we remain focused on the role of non-state actors within the UNFCCC. In this institutional context, non-state actors are increasingly on numerical parity with government delegates, and delegations also progressively include more non-state actors (Willetts, 2009; Schroeder et al., 2012). COP21 in Paris gathered almost 40,000 delegates, of 
which 25000 were from governmental representatives, and the remaining civil society, UN agencies, and media organizations. ${ }^{13}$ Non-state actors perform diverse functions such as organizing side-events, providing expertise and information, lobbying national delegates, organizing protests, monitoring of implementation, and so on (Schroeder and Lovell, 2012). As this brief survey suggests, non-state actors are a vital part of the UNFCCC. But questions abound about whether, how, and to whom these non-state actors are accountable (Newell, 2008).

Non-state Actors within the UNFCCC: Observer Organizations and Constituency Groups

Because of the importance of the institutional framework for accountability, we elaborate on the UNFCCC constituency system and its rules, norms, and procedures to facilitate analysis. At COP21 in Paris, more than 2000 observer organizations were accredited and admitted. These observer groups are clustered into nine constituencies with diverse but recognizable interests. This model of institutionalized participation emerged from the United Nations Conference on Environment and Development (UNCED) in 1992 where Agenda 21 divided civil society into UN major groups. The UNFCCC has subsequently adopted such a system of organizing civil society into constituencies to facilitate coordination and interaction with government delegates. The first two constituency groups to organize within the UNFCCC system were the Business and Industry NGOs (BINGO) and the Environmental NGOs (ENGO). At COP1 in 1995 local government and municipal authorities (LGMA) joined the fold, followed by the indigenous peoples organizations (IPO) at COP7 in 2001, the research and independent NGOs (RINGO) at COP9 in 2003, and the trade union NGOs (TUNGO) before COP14/CMP4 in 2008. Women and Gender (WGC) along with Youth NGOs (YOUNGO) became full constituencies in 2007 just before COP17. Currently farmers and agricultural NGOs (Farmers) have provisional status as a constituency group. ${ }^{14}$

These nine constituency groups contain more than $90 \%$ of all NGOs admitted during each COP (with Climate Justice Now! (CJN) notably missing). Although there is clearly much

\footnotetext{
${ }^{13}$ https://www.carbonbrief.org/analysis-which-countries-have-sent-the-most-delegates-to-cop21 (accessed 15 August 2016).

${ }^{14}$ Farmers are awaiting approval as formal constituency following the recent accreditation of the World Farmers Organization as an observer organization under the UNFCCC, the organization holding the focal point of the constituency.
} 
cross-over between the groups, each constituency stands for a particular set of interests and ideas. Observer groups are allowed to list themselves with more than one constituency group when they become accredited but this is not a prolific choice, indicating that many groups do feel aligned with their constituency. While being part of a constituency group is not essential, it is certainly beneficial for observer groups. Constituency members receive: access to the Plenary floor so as to make interventions; allocation of secondary badges when site access is limited; advance information from the Secretariat; access to daily meetings with their constituency group; occasional invitations to Ministerial receptions; access to bilateral meetings with officials; and invitation by the Secretariat to limited-access workshops between sessional periods.

Structurally, each constituency interacts with the Secretariat through a focal point: an individual chosen as a representative on behalf of the constituency. ${ }^{15} \mathrm{Six}$ of the groups have one focal point (BINGO, ENGO, TUNGO, RINGO, LGMA, and Farmers) and the remaining three (Women and Gender, IPO, and YOUNGO) have two focal points. The job of the focal point is to: channel information between the Secretariat and the constituency members; assist the Secretariat in ensuring effective NGO participation (i.e. UNFCCC rules are followed by observer groups); and provide logistical support to their constituencies during session. For instance, the focal point coordinates observer interactions at sessions, convenes constituency meetings, organizes meeting with officials, provides names for speaker lists, and offers "representation at official functions" (Kuyper and Bäckstrand, 2016). This occurs at semi-annual meetings when all focal points meet with the Secretariat to convey the interactions between, and interests of, their constituency organizations. The focal point also assists "the Secretariat in realizing representative observer participation at workshops and other limited-access meetings."16

From this institutional overview, it is clear that many non-state actors operate within the UNFCCC institutional framework. Numerous NGOs are admitted as observers, work within constituency groups, and interact with the Secretariat through focal points of those constituencies. Institutional rules, procedures, and norms provide some ways for non-state actors

\footnotetext{
${ }^{15}$ For a detailed examination of how individual focal points are selected, see (Kuyper and Bäckstrand, 2016). ${ }^{16}$ UNFCCC, Non-Governmental Organization Constituencies. Available at: https://unfccc.int/files/parties_and_observers/ngo/application/pdf/constituencies_and_you.pdf (accessed 12 December 2015).
} 
to demand justifications from each other. ${ }^{17}$ In turn, it is the shared institutional space which provides scope for mechanisms of exit, voice, and loyalty to be used, tested, and recalibrated over time as non-state actors seek to sanction one-another. Although this occurs across constituency groups, most of the empirical examples we excavate are from within intraconstituency battles.

\section{Institutional Accountability through Exit, Voice, and Loyalty}

Before beginning the analysis, a more in-depth discussion of our methodology and data collection is warranted. In analyzing the UNFCCC as an illustrative case-study to unpack the logic of institutional accountability, we draw upon four years of on-site observation at COPs and Intersessionals. While this does not rise to the level of collaborative event ethnography (Campbell et al., 2014), we undertook extensive field notes from meetings, collected documentation, and undertook more than 40 semi-structured interviews with state and non-state actors. To control for observer bias, we had multiple discussions between the authors of this paper on how to reconcile our impressions and views taken at the venues. The next three subsections discuss how different non-state actor constellations employed rules, norms, and procedures in conjunction with exit, voice, or loyalty to generate accountability of other nonstate actors within constituencies. We explicitly focus on the outcomes of exit, voice, and loyalty to demonstrate how these mechanisms actually create sanctions (both positive and negative). We draw examples from different non-state actors within the UNFCCC without focusing specifically on any constituency or moment in time. As such, some constituency groups are not looked at, such as RINGO, which does not have a mandate for policy advocacy. We limit ourselves in this way because of space constraints, but also to provide a level of generalizability to our argument as we are looking at illustrations of institutional accountability in practice, not testing how each constituency operates. $^{18}$

\footnotetext{
${ }^{17}$ Because each constituency group represents a set of interests, it is likely that the standards of accountability vary between the groups. Accountability wielders, though, also consider that accountability holders should operate according to the rules, norms, and procedures of the institutional space they occupy.

${ }^{18} \mathrm{We}$ have also not looked explicitly at Farmers or IPO. These constituencies certainly provide interesting examples of accountability (especially as they, in their relatively new state, seek to legitimate themselves) are excluded due to space restrictions.
} 
Exit represents an important mechanism for generating accountability. The theoretical logic underpinning this mechanism is that actors working within an institutional framework can demand justifications from one-another through rules, norms, and procedures and - if the justification is not deemed adequate - the actor can remove support and resources by exiting the relationship. As Mathias Koenig-Archibugi (2005, p. 122) has suggested when discussing how transnational corporations (TNCs) are increasingly able to shift operations between different countries and jurisdictions, "opportunities for 'exit' turn the accountability relationship upside down by making governments accountable to TNCs." We look at both qualified and complete variants of exit in this analysis.

On qualified exit, non-state actors within the UNFCCC often ask questions of oneanother and, if the justifications are not acceptable, threaten to shift their allegiances to other actors under the same institutional framework. Within the UNFCCC this could mean joining an alternative faction within a constituency group or joining another constituency group altogether. Precisely because there are many networks operating within the same institutional framework, we argue that institutional accountability represents a distinct ideal type. A key example of this mechanism emerged from our interviews and observations with the YOUNGO constituency. In this constituency battles for accountability play out between members and the focal point. Members have the opportunity to demand answers from the focal point at daily meetings, which is a rule mandated by the Secretariat. However, if focal points do not provide adequate responses, there are few formal mechanisms for sanctioning.

One mechanism available, though, is to make use of qualified exit. We observed this when members of the YOUNGO constituency told us that a key strategy for them to hold the focal point to account is by creating working groups which can be employed to "bring issues within your orbit" (L. Kemp, Interview, 2014). Although working groups already exist within the constituency, actors take it upon themselves to bypass the focal point, create new working groups, and use this as a way to shift support. Once a working group is established, actors can use the platform as a way to mobilize additional support and address the Secretariat directly without using the focal point as an intermediary. In further interviews, one of the focal points of YOUNGO noted that the creation of alternative working groups hampered their efforts for 
streamlining the position of YOUNGO and made their task more demanding (S. Marquant, Interview, 2014). This strategic use of qualified exit thus shows how actors can use formal rules and procedures (by creating competing working groups within a constituency) to shift support away from focal points as a way to sanction them (by removing power and support from their mandate). Because actors often do not have a monopoly within the constituency, qualified exit is possible as a sanctioning mechanism (Hirschman 1970, p. 26).

An example of using 'complete exit' to generate institutional accountability can also be derived from the constituency system of the UNFCCC. In some cases - notably BINGO and ENGO - single networks do dominate a constituency (Kuyper and Bäckstrand, 2016). In these instances of monopoly, complete exit is the more likely mechanism for sanctioning. ${ }^{19}$ Perhaps the most prominent example of this came in 2007 at the COP in Bali when a new network of activists - Climate Justice Now! - was launched. This represented a split from the remainder of the ENGO constituency where the mainstream Climate Action Network (CAN) allocated the constituency focal point (Hadden, 2015; Reitan \& Gibson, 2012). In Bali CJN decided to leave ENGO entirely in the hands of CAN and seek to mobilize a radical, outsider critique of the climate change negotiations (CJN, 2007). Today around 400 organizations belong to CJN with the primary goal of the network being to take action "on the ground and in the streets". ${ }^{20}$ Although some member organizations of CJN remain observers to the UNFCCC, the network itself operates externally to ENGO, thus being an example of complete exit. ${ }^{21}$ This case then highlights the difference between 'networked accountability' (in which justification demands arise between network members) and institutional accountability (in which the wider framework provides rules, norms, and procedures for actors in different networks to demand justifications from one-another). In this instance the institutional framework allowed some members to not only leave the network of CAN (as we would see in networked accountability) but also to relocate to another part of the institutional system and continue using this framework to pressure actors in other networks.

\footnotetext{
${ }^{19}$ We thank a reviewer for impressing this point upon us.

20 Climate Justice Now! discussion list. Available at: https://lists.riseup.net/www/info/cjn (accessed 18 October 2015).

${ }^{21}$ From the 2015 constituency information document released by the UNFCCC Secretariat, CJN is not included as constituency in ENGO nor given a focal point. This illustrates the 'complete exit' adopted by CJN. See https://unfccc.int/files/parties_and_observers/ngo/application/pdf/constituency_focal_point_contact_details.pdf (accessed 18 October 2015).
} 
A methodological limitation facing analysis of CAN-CJN, however, is that virtually all of our interviewees from ENGO were reluctant to speak about the fractions between CAN and CJN. For example, one interviewee admitted internal divisions in the past, but claimed that relationship between CJN and CAN are healing as they have joint meetings and coordination (T. Athanasiou, Interview, 2015). Despite this, there were several reasons underpinning the split of CJN from CAN. The root of the exodus was a divide between the first generation of reformoriented pragmatic climate movement, embodied in CAN, and the second generation anticapitalist, system-critical radical climate justice movement of CJN (Bond, 2012; Hadden, 2015; Reitan \& Gibson, 2012). Division was spurred on by an ideological factor: years of multilateral gridlock and frustration, especially after Copenhagen, with weak outcomes in terms of curbing carbon emissions radicalized and diversified the climate movement in terms of both ideology and tactics. The fault-line between the reformist, science-based, and hierarchical CAN and the radical, anti-systemic, and horizontal CJN widened as issues - such as the role of market-based mechanisms in the Kyoto Protocol - rose on the international agenda. Many members of CJN felt that CAN had become too diverse and unwieldy. This diversity led to the impression that several core positions within the group were irreconcilable, such as CAN's support of emissions trading. As one interviewee stated, "CAN want to do what is politically feasible while CJN want to do what is right" (N. Amerasinghe, Interview, 2015). Resultantly, key members of CJN did not think CAN spoke sufficiently on behalf of the most vulnerable communities to climate change (Reitan \& Gibson, 2012, p. 398).

Secondly, there was a pragmatic reason that caused the split to occur when it did: facilities at Bali were not large enough to hold both CJN and CAN members. This logistical problem was aggravated at COP15, where the conflict between CAN member and CJN centered around the limitation of badges, and the smaller network of CJN received $40 \%$ of the badges. The institutional constraints to climate activism were further reinforced at COP21 Paris, where protest and demonstration was curtailed by the UNFCCC secretariat in the wake of the terror attack (Orr 2016). Because of the lack of facilities, the ability for CJN members to demand justifications from CAN and other ENGO members became limited. A third reason for the complete exit was the antagonism of the UN and interstate system epitomized by CJN slogans such as NTAC (Never Trust a COP) at Copenhagen and "No deal is better than a bad deal" (Hadden, 2015; T. Anderson, Interview, 2013). The UN system, according to CJN, propagates a 
false market-based and technological solution from government and corporate elites from above (Bond, 2012).

Exiting ENGO and shifting activities outside of ENGO and (in some cases) the UNFCCC was invoked by CJN as a form of accountability. After using UNFCCC rules, norms, and procedures to discuss issues and probe justifications from CAN, it became increasingly clear that CAN were not able or willing to take on-board more radical policies and distance themselves from market-based solutions. The ground for exit was discontent with CAN's main pragmatic strategy that focused on inside lobbying tactics with the aim to influence negotiations: "CAN acts as lobbyists in suits instead of being a watchdog environmentalists engaged in outside protests" (T Anderson, Interview, 2013). CAN's strategy stood in sharp contrast to climate justice activists' effort to break the fence and police line at Bella Center at COP15 in Copenhagen in order to take over the conference and hold the People's Assembly for Climate Justice (Reitan \& Gibson, 2012, p. 402; Fisher \& Galli, 2015). In this instance disagreements over procedural rules (allocation of badges) and substantive normative commitments (mitigation pathways) acted as accountability standards, and members of the CJN decided to cut with CAN and exit the broader institutional framework, taking many members and resources with them.

The complete exit of CJN was thus an attempt to hold CAN accountable for their (lack of) action at the COPs. As noted by Jennifer Hadden (2015, p. 50) in her analysis of CJN members, one advocate stated that completely exiting the UNFCCC organization was imperative to hold big NGOs accountable. The activist argued that CAN "are totally unable to react to the most important political issues of the COP...We [CJN] showed them that we really want change; we aren't going to wait behind our stands and hand out stupid leaflets". While tracing the precise effect of CJN exit on CAN policy or behavior is difficult, the fact that CAN members have attempted to heal the rift indicates that there have been some efforts made in response to the negative sanctioning (Anonymous, Interview, 2014). Resultantly, it is clear that exiting an institutional framework - either partially or completely - provides a way to sanction other nonstate actors for their actions and inactions by removing resources and members.

\section{Voice}


Another mechanism to induce institutional accountability comes through voice. Theoretically voice works by using rules, procedures, and norms to demand justifications from other actors within the same institutional framework. Once justifications are received, actors can either positively or negatively sanction the justifier through continual usage of voice. This can be done vertically - by directing praise or criticism toward the justifier - or horizontally - by talking with other members of the institutional framework. From within the UNFCCC institutional system, we observe that non-state actors use voice to generate both positive and negative sanctions. Voice is likely to be used when loyalty is high and the prospects of effective exit as a sanctioning device are low (Hirschman 1970, p. 37).

We commence with a discussion of voice used to sanction a justifier positively. The LGMA constituency seeks to showcase the potential of sub- and non-state action in redressing climate change. They do so through dialogue with other actors in the climate regime and not by engaging in protests. Local and subnational actors argue that they can enrich and enhance global strategies when appropriately included and enabled to do so. As such, the core emphasis is on demonstrating the important role that LGMAs can play in implementing international and national climate policy. Constituency members seek to increase visibility and obtain commitments on the part of national governments to work more closely with their subnational/local counterparts. As such there are several common goals that unite members of the LGMA constituency and command continual positive usage of voice on the part of its member organizations. In the words of an interviewee, "cities have committed to ambitious action, they make themselves accountable and visible via registries and huge collaborative unities" (S. Nolden, Interview, 2015). Cities and municipalities wish to be included, enabled, and mandated to play their role. At the same time, the constituency is encouraging national governments to have more local government representatives on their delegations.

The LGMA constituency is made up of city representatives and representatives of the various global and regional city networks. The most prominent organization within LGMA is Local Governments for Sustainability (ICLEI), a city network, which maintains the focal point role for LGMA. In light of this role, ICLEI see themselves as bridges or translators between cities and the UNFCCC. As the UNFCCC negotiation process is becoming increasingly complex, and cities are becoming more competitive with each other, ICLEI and other transnational alliances are working toward enabling a two-way dialogue between cities and the 
UNFCCC, in order to "get the politics and the realities on the ground together" (Y. Arikan, Interview, 2013). ICLEI's goal, in particular, is to create cities that are sustainable, resilient and transformative. Many cities are members of networks, associations and agreements, all of which are inter-connected as well and cross-fertilize each other - "the city networks together have a bigger mandate and bigger outreach" (S. Nolden, Interview, 2015).

From interviews and on-site observation, it has become clear that members of the LGMA constituency often invoke positive voice to sanction the constituency focal point - Yunus Arikan - and ICLEI activities in general. ${ }^{22}$ In 2014 in Lima, the authors sought to attend morning meetings three days in a row. The focal point, against UNFCCC procedures, either cancelled or failed to attend said meetings the first two times. On the third occasion the focal point turned up almost an hour late and gave a five minute briefing in the hallway outside the meeting room. Although members of the constituencies were able to demand justifications, there was discontent about the lack of communication from the focal point and other ICLEI members. Subsequent to this meeting, in an on-site discussion with an LGMA member, the authors asked about the lack of information from the focal point and the general frustration about the cancelled meetings. This respondent stated that, although meetings had been delayed or cancelled, it was due to the amount of hard work undertaken by Arikan and other ICLEI members. The respondent suggested that the positive impact generated in negotiations by ICLEI warranted less responsiveness. As a result, this positive voice helps sanction ICLEI and the focal point in their work by quelling dissensus amongst other members (horizontal) and providing the organization with social capital and resources (vertically) that aid in presenting a coherent position. It is therefore clear that the LGMA focal point seeks to secure loyalty in order to increase the likelihood of positive voice.

By contrast, an example of negative voice can be drawn from many instances, and we focus here upon recent on-site observation at daily meetings at COP21 in Paris. These meetings are both functional - involving the dissemination of information from the Secretariat, giving out tickets to selected events, discussing housekeeping issues - and sites of political and accountability battle. Political battles unfold over, inter alia, strategies for influencing negotiations, the wording of Plenary speeches made by the constituency, the type of wording

\footnotetext{
${ }^{22}$ It is also clear from our data and analysis that LGMA strives to build loyalty in order to make voice more likely instead of exit (i.e. to generate elasticity when demands for justification rise). Inversely, voice is more powerful as a sanctioning mechanism when exit is a viable mechanism. See Hirschman, 1970, p. 76.
} 
wanted by different groups within the constituency in negotiation texts, and so on. The morning meeting is led, in almost all cases, by the constituency focal point in their role as intermediary between the observer organizations within the constituency and the Secretariat.

At COP19, 20, and 21, the authors attended daily meetings for many of the constituency groups (not all because some - such as BINGO and CAN - are closed to non-constituency members). In the second week of COP21, a clear example of negative voice emerged at a morning meeting of the TUNGO constituency. The penultimate draft of the Paris Accord had been released and there was a discussion about what issues had been included and excluded from the finalizing document. The morning meeting was chaired by Anabella Rosemberg who is the TUNGO focal point and representative of the International Trade Union Confederation (ITUC).

As the meeting wore on, a major source of contention emerged between different factions. The split concerned the wording of the Paris Agreement draft text and the lack of inclusion of the phrase 'just transition'. TUNGO as a constituency had decided several years previously to focus on making sure that any UNFCCC climate agreement remained explicitly concerned with the retraining of workforces whose jobs would be displaced under a shift toward low carbon technologies (P. Colley, Interview, 2015). In the penultimate draft of the Paris Agreement, however, 'just transitions' had been included in the decision, but not in the Annex. ${ }^{23}$ This was viewed as a substantive loss for the constituency group as it indicated that the phrase would not be part of the legally binding section of the Paris Agreement. At the meeting it became clear that some constituency members agreed that all had been done to secure the desired outcome, whereas other constituency members voiced their concerns that ITUC and other influential trade union groups had not lobbied hard enough.

This case represented an instance of institutional accountability because observers within the TUNGO constituency were able to use the morning meeting to demand justification from the focal point and ITUC about their strategy to have just transition included in the text. It sanctioned ITUC and the focal point through negative voice as it became clear over the course of an hour and twenty minutes that more and more members of the constituency were dissatisfied with the omission through horizontal diffusion. One group of members, not from ITUC, started to hand out t-shirts from their group in quite a disruptive manner. The meeting ran more than 20

23 In the final draft, 'just transition' was included in the Annex, but only in the Preamble, not in an Article. 
minutes over time and Rosemberg was forced to stay longer, justifying her and ITUC's position. By the end, Rosemberg had made quite a long, impassioned, and perhaps even acerbic speech documenting the efforts made by ITUC over the years, stating that no-one in the constituency could claim that ITUC and herself had not worked tirelessly, losing sleep, to have 'just transition' included in the Paris Agreement. ${ }^{24} \mathrm{We}$ consider this expenditure of time and effort and effect of the use of negative voice as a sanctioning. The use of morning meetings to demand justifications is a procedure to be followed by each constituency. The ongoing usage of voice to demand answers, mobilize others, and force further justifications is a key example of institutional accountability at play. And although ITUC does go to lengths to secure loyalty, in this instance it was not sufficient to stem the initiation of quite public contestation.

\section{Loyalty}

Finally, actors can opt to remain loyal in light of justifications; this helps provide capital, resources, and support for the justifier. As noted previously, in line with Hirschman's (1970, p. 93) theory, accountability holders can seek to secure loyalty as a way to postpone exit and encourage voice. Several of the constituencies - such as BINGO and the Women and Gender Constituency (WGC) - display high degrees of loyalty from member organizations that contribute to positively sanctioning the focal points and other leaders of the constituency. ${ }^{25} \mathrm{We}$ draw cursory examples from both constituencies in this section. Although loyalty moderates the usage and effects of exit and voice, we identify loyalty in practice through the absence of either positive/negative voice or exit despite instances of disagreement.

Along with ENGO, BINGO is the longest-standing and most active constituency. Its diverse membership ranges from green pro-regulatory coalitions of companies to anti-regulatory and even climate-skeptical members. As documented by researchers (Vormedal, 2008; Yamin \& Depledge, 2004, pp. 52-54), the BINGO constituency has from its inception been divided between "gray" anti-mitigation fossil-fuel companies and "green" pro-regulation companies. In the words of an interviewee, the World Business Council of Sustainable Development (WBCSD)

\footnotetext{
${ }^{24}$ Author observation from COP21 in Paris. December 10, 2015.

25 RINGO is also largely built on loyalty as the constituency has a policy not to engage in advocacy. Rather members are expected to remain loyal to the constituency-wide position.
} 
represents the big fossil side industry, the International Chamber of Commerce (ICC) the centrist position, while the European Business Council of Sustainable Energy represents the green end (S. Gallehr, Interview, 2015).

However, despite deep internal rifts, the BINGO constituency puts great efforts into generating loyalty: presenting themselves as a single unified constituency to provide a coherent business perspective on climate change (Yamin \& Depledge, 2004; J. Drexhage, Interview, 2015; M. Mendiluce, Interview 2015). In doing so, BINGO maintains closed-door meetings and private events. While it is clear that BINGO is divided between 'green' and 'brown' carbon emission reduction efforts, these views are rarely aired in public. Several interviewees from BINGO stressed to us "the ability of their organization to work out issues internally without wider consultation" (B. Black, Interview, 2013). Unlike ENGOs and other constituencies, however, BINGOs do not engage in policy advocacy in the UNFCCC. As one interviewee put it - by way of contrast to internal battles within ENGO - while BINGO members differ in positions when lobbying governments, when coming to COP they put their differences aside and unite around a business perspective on climate change. BINGO manages to speak with a single voice by: presenting general policy options; demanding regulatory certainty; seeking marketbased mechanisms; and striving toward less bureaucracy, better regulatory design, and a business-friendly environment (Yamin \& Depledge, 2004, p. 53; J. Drexhage, Interview, 2015). It is possible sometimes to see the emergence of splits between BINGOs at the COP when actors use rules, norms, and procedures to demand justifications from others. For instance, the ICC, who assigns the focal point for BINGOs, has ExxonMobile as a strong and influential member known for the most aggressive anti-climate stance among all oil companies. This prevented ICC from adopting a stronger pro-regulatory climate stance (Vormedal, 2008, p. 40). Likewise, when greener members of BINGO requested to make separate interventions in the negotiations, the ICC introduced an annex in 2003 to accommodate this request. This annex made it possible to make more far-reaching statements on the role of industry in promoting the transition to renewables (S. Gallehr, Interview, 2015). But overall, despite disagreement in terms of substantive issues, we observe strong loyalty toward BINGO as a whole (M. Mendiluci, Interview, 2015; S. Gallehr, Interview, 2015; J. Drexhage, Interview, 2015). Differences are manifest when individual BINGO members make use of formal and informal networks to lobby individual governments and delegations be it for renewable energy, fossil fuels, nuclear, or 
Carbon Capture and Storage. But within the UNFCCC, BINGO relies upon (and even privileges) loyalty to generate coherence for the business perspective.

Another example of loyalty comes from the WGC, which is one of the smallest of UNFCCC constituencies (comprising of around 15 civil society organizations) with the overall aim to promote a gender and human rights perspective in the UN climate negotiations (Olson, 2014). Despite its strong activist history rooted in feminist movements in the South, WGC is as today dominated by loyalty from its membership organizations. After 20 years of activism in UN negotiations through networks such as Women in Environment and Development (WED), WGC was formalized as a UNFCCC constituency in $2009 .{ }^{26}$

The constituency stresses the importance of accountability mechanism to discourage exit and negative voice, but also to secure support behind joint positions in the climate negotiations (G. Alber, Interview, 2013: K. Cahoon, Interview, 2015; U. Nair, Interview, 2014, 2015). In doing so, the WGC has two elected focal points - one from the North and one from the South to secure that the diversity of women's voices is included. Furthermore, different thematic working groups have been established such as on Mitigation, Loss \& Damage, and Finance and Technology Transfer as way to secure accountability (K. Cahoon, Interview, 2015). The daily morning Women Caucus meeting at COPs (open also to non-constituency members) is a venue to resolve differences and build consensus. When differences in opinions occur, the WGC take great effort to deliberate internally and resolve conflicts (U. Nair, Interview, 2015).

As a constituency with a long history of being based in social and grassroots movements, the WGC is an outlier compared to BINGO and LGMA, which have appointed focal points outside UNFCCC process through (respectively) the ICC and ICLEI. At COP20 in Lima, WGC decided to move into strategic policy advice as "gender mainstreaming" has been adopted as an official strategy by the UNFCCC (K. Cahoon, Interview, 2015; Olson, 2014). Consequently, in Paris, WGC started having closed meetings for constituency members only, which is a response to the need to speak with a coherent voice when approaching governments and UNFCCC. The main task of WGC has recently shifted to provide expertise and influence governments and the UNFCCC to secure gender equality in policies on climate mitigation and adaptation, while outsider tactics of protests and demonstrators have taken a more secondary role (U. Nair,

\footnotetext{
${ }^{26}$ WGC website: http://womengenderclimate.org, accessed December 27, 2015.
} 
Interview, 2015). Hence, the constituency has developed internal accountability mechanisms to secure support for its policy positions. In other words, although this constituency has many rules, norms, and procedures to demand justifications from one-another, steps - such as closing the constituency meetings - are being taken to ensure that loyalty - at least in public terms - is the mechanism adopted by most constituency members.

Overall, BINGO and WGC put a premium on loyalty. Although actors often demand justifications from other constituency members and the focal point, this is done behind closed doors. This enables actors to voice grievances privately while continuing to stay loyal to the constituency publicly. This public loyalty acts as a positive form of sanctioning by increasing perceptions of unity, rewarding constituency leaders with de facto support, and mitigating the need for leaders to spend additional time and resources on quashing dissent. Efforts to deal with constituency-wide heterogeneity behind closed doors then leads to increased loyalty from constituency members (accountability holders), which in turn increases the likelihood of continued voice over exit. As such loyalty is an important element of institutional accountability.

\section{Conclusion}

In conclusion we summarize our key findings and highlight future avenues for research. This paper has developed and empirically applied the concept of institutional accountability and juxtaposed it against delegation, participation, and networked modes of accountability. We argue that institutional accountability arises when actors, sharing the same institutional framework, use rules, norms and procedures to demand justification from one-another. In light of those justifications, accountability wielders then combine mechanisms of exit, voice, and loyalty to sanction - reward or punish - the accountability holder.

In order to show how institutional accountability works in practice we conducted an illustrative case study of accountability struggles between non-state actors within the UNFCCC. We depicted the general structure of the UNFCCC constituency system with a diversity of observer organizations - NGOs, industry groups, local government groups, indigenous and women movements - grappling for space, recognition, and influence in the wider system. Under 
this institutional framework non-state actors routinely demand justifications from one another at daily meetings, in working groups, in liaison with the Secretariat, in official plenary sessions, in discussions with the focal point, and so on. Actors can then use exit, voice, and loyalty as mechanisms for sanctioning these justifications. We provided examples from a raft of observer organizations and constituency groups. This helps unpack how rules, procedures, and norms (structural features) combine with informal mechanisms to produce accountability of non-state actors in UN climate diplomacy (agentic choices). It enables us to look at how power struggles for accountability play out between non-state actors themselves in ways that shape the strategy and position of different constituency groups. Although it might be argued that our analysis simply captures power struggles between actors, our empirical material traces the necessary conditions of accountability - demanding justification and leveraging sanctions in light of those justifications - we have focused specifically on the politics of institutional accountability. Indeed, we argue it would be a mistake not to view certain power struggles through the lens of accountability.

Finally, this recognition of institutional accountability generates several future avenues of research and we focus here on two in particular. On one hand, other scholars should seek to determine the scope of institutional accountability. Does it apply only to non-state actors, or do states also engage in mechanisms of exit, voice, and loyalty within institutional frameworks to demand accountability? Moreover scholars should analyze whether institutional accountability arises in other areas such as the UN High-Level Political Forum negotiating the sustainable development goals and the post-2015 development agenda. Given the enormous range of institutions that compose governance beyond the state, this form of accountability may offer insight into the politics of accountability within those structures. On the other hand, scholars should also seek to determine the conditions under which institutional accountability actually occurs and when exit, voice, and loyalty is successful in practice. When do actors choose to engage exit, voice, or loyalty? Which is more successful in changing the accountability holder's behavior in the future? As non-state actors continue to exercise influence and authority, understanding how institutional accountability constrains and empowers these actors is critical as we seek to map and assess the legitimacy and effectiveness of climate governance.

\section{References}


Balboa, C. (Forthcoming) Mission interference: How competition confounds accountability for environmental nongovernmental organizations. Review of Policy Research.

Barry, B. (1974). Review article: Exit voice and loyalty. British Journal of Political Science 4(1): 79-107.

Betsill, M. M., \& Corell, E. (2001). NGO Influence in International Environmental Negotiations: A Framework for Analysis. Global Environmental Politics 1(4), 65-85.

Betsill, M. M., \& Corell, E. (2008). NGO diplomacy: The influence of non-governmental organizations in international environmental negotiations. Cambridge, MA: MIT Press.

Betsill, M. M., Navroz K. Dubash, Matthew Paterson, Harro van Asselt, Antto Vihma and Harald Winkler. (2015). "Building Productive Links between the UNFCCC and the Broader Global Climate Governance Landscape." Global Environmental Politics 15 (2): $1-10$.

Biermann, F., Pattberg, P., van Asselt, H., \& Zelli. F. (2009). The fragmentation of global governance architectures: A framework for analysis. Global Environmental Politics 9 (4), 14-40.

Bond, P. (2012). Politics of Climate Justice: Paralysis Above, Movement Below. South Africa: University of KwaZulu Natal Press.

Bomberg, E. (2012). Mind the (Mobilization) Gap. Comparing Climate Activism in the United States and the European Union. Review of Policy Research 29(3), 408-430.

Bäckstrand, K. (2008). Accountability of networked climate governance: the rise of transnational climate partnerships. Global Environmental Politics 8(3), 74-102.

Campbell, L. M., Corson, C., Gray, N. J., MacDonald, K. I., \& Brosius, J P. (2014). Studying Global Environmental Meetings to Understand Global Environmental Governance: Collaborative Event Ethnography at the Tenth Conference of the Parties to the Convention on Biological Diversity. Global Environmental Politics 14(3), 1-20.

CJN. (2007). What's missing from the climate talks? Justice!, press release, 14 December. Retrieved from: http://www.foei.org/en/media/archive/2007/whats-missing-from-theclimate-talks-justice/.

Derman, B. (2014). Climate governance, justice, and transnational civil society. Climate 
Policy 14(1), 23-41.

Dowding, K., John, P., Mergoupis, T., \& van Vugt., M. (2000). Exit, voice and loyalty: Analytic and empirical developments. European Journal of Political Research 37, 469-95.

Fisher, D., \& Galli, A. (2015). Civil Society. In K. Bäckstrand and E. Lövbrand (Eds.), Research Handbook on Climate Governance. London: Edgar Elgar.

Friedman, E. J., Hochstetler, K., \& Clark, A-M. (2005). Sovereignty, Democracy and Global Civil Society: State-Society Relations at UN World Conference. New York: State University of New York Press.

Gates, S. \& Hill, J. (1995). Democratic Accountability and Governmental Innovation in the Use of Non-profit Organizations. Review of Policy Research, 14 (1-2), 137-148.

Gerlak, A. K. (2015). Resistance and reform: Transboundary water governance in the Colorado River Delta. Review of Policy Research, 32(1), 100-123.

Grant, R., \& Keohane, R. O. (2005). Accountability and Abuses of Power in World Politics. American Political Science Review 99(1), 29-44.

Green, J. (2014). Rethinking Private Authority. Agents and Entrepreneurs in Global Environmental Governance. Princeton and Oxford: Princeton University Press.

Hadden, J. (2014). Explaining Variation in Transnational Climate Change Activism: The Role of Inter-Movement Spill-over. Global Environmental Politics 14(2), 7-25.

Hadden, J. (2015). Networks in Contention. The Divisive Politics of Climate Change. Cambridge: Cambridge University Press.

Hale, T. (2016). All Hands on Deck. The Paris Agreement and Nonstate Climate Action. Global Environmental Politics 16(3), 12-22.

Hirschman, A. O. (1970). Exit, Voice, and Loyalty: Responses to Decline in Firms, Organizations, and States. Cambridge, MA.: Harvard University Press.

Johnson, C. (forthcoming). Accountability without Borders: Problems of Sovereignty and Responsibility in the Global Climate Regime. Review of Policy Research.

Jordan, A. J., Huitema, D., Hildén, M., van Asselt, H., Rayner, T. J., Schoenefeld, J. J., Tosun, J., Forster, J., \& Boasson. E. L. (Forthcoming). Emergence of polycentric climate governance and its future prospects. Nature Climate Change. doi:10.1038/nclimate2725.

Keohane, R. O. (2003). Global Governance and Democratic Accountability. In Held, D., \& 
Koenig-Archibugi, M. (Eds.), Taming Globalization: Frontiers of Governance. London: Polity Press.

Keohane R. O., \& Victor. D. (2011). The Regime Complex for Climate Change. Perspectives on Politics 9(1), 7-23.

Koenig-Archibugi, M. (2005). Transnational Corporations and Public Accountability. In D. Held \& Koenig-Archibugi, M. (Eds.), Global Governance and Public Accountability. Oxford: Blackwell Publishing.

Kramarz, T., \& Park, S. (2016). Accountability in Global Environmental Governance: A Meaningful Tool for Action? Global Environmental Politics 16(2), 1-21.

Kramarz, T., \& Park, S. (forthcoming). The Politics of Purpose in Environmental Accountability. Review of Policy Research.

Krasner, S.D., 1982. Structural causes and regime consequences: regimes as intervening variables. International organization, 36(2), 185-205.

Kuyper, J. W., \& Bäckstrand, K. (2016). Accountability and Representation: Nonstate Actors in UN Climate Diplomacy. Global Environmental Politics 16(2), 61-81.

Macdonald, T. (2008). Global Stakeholder Democracy: Power and Representation Beyond Liberal States. Oxford: Oxford University Press.

Nasiritousi, N, Hjerpe, M., \& Buhr, K. (2014). Pluralising Climate Change Solutions: Views Held and Voiced by Participants at the International Climate Negotiations. Ecological Economics 105(September), 177-84.

Newell, P. (2008). Civil society, corporate accountability and the politics of climate change. Global Environmental Politics 8(3), 122-153.

Olson, J. (2014). Whose Voices Matter? Gender Equality in the United Nations Framework Convention on Climate Change. Agenda 28(3), 184-187.

Omelicheva, M. (2009). Global Civil Society and Democratizing of World Politics. A Bona Fide Relationship or Illusory Liaison? International Studies Review 11, 109-132.

Ovodenko, A. (2014). The Global Climate Regime: Explaining Lagging Reform. Review of Policy Research 31(3), 173-198.

Orr, S. (2016). Institutional Control and Climate Change Activism at COP21 in Paris. Global Environmental Politics 16(3), 23-30.

Pattberg, P., \& Widerberg, O. (forthcoming). Accountability Challenges for Cooperative 
Initiatives in Global Climate Governance. Review of Policy Research.

Reitan, R., \& Gibson. S. (2012). Climate Change or Social Change. Environmental and Leftist Praxis and Participatory Action Research. Globalizations 9(3), 395-410.

Rosental, C.S., Rosental, J.A., Moore, J. \& Smith J. (2015). Beyond (and Within) City Limits. Climate Policy in an Intergovernmental System. Review of Policy Research 32(5), 538555.

Scholte, J. A. (2004). Civil Society and Democratically Accountable Global Governance. Government and Opposition 39(2), 211-33.

Schroeder, H., Boykoff, M., \& Spiers, L. (2012). Equity and State Representations in Climate Negotiations. Nature Climate Change 2, 834-836.

Schroeder, H., \& Lovell, H. (2012). The role of non-nation-state actors and side events in the international climate negotiations. Climate Policy 12(1), 23-37

Slaughter, A-M. (2004). A New World Order. Princeton: Princeton University Press.

Stevenson, H., \& Dryzek, J. S. (2014). Democratizing Global Climate Governance. Cambridge: Cambridge University Press.

Vormedal, I. (2008). The Influence of Business and Industry NGOs in the Negotiation of the Kyoto Mechanisms: the Case of Carbon Capture and Storage in the CDM. Global Environmental Politics 8(4), 36-65.

Willetts, P. (2011). Non-governmental Organizations in World Politics. The Construction of Global Governance. London \& New York: Routledge.

Yamin, F. \& Depledge, J. (2004). The International Climate Change Regime. A Guide to Rules, Institutions and Procedures. Cambridge: Cambridge University Press.

Young, O. (2002). The Institutional Dimensions of Environmental Change: Fit, Interplay and Scale. Cambridge, MA: MIT Press. 


\section{Appendix A - List of Interviewees}

\begin{tabular}{|l|l|l|l|}
\hline Name & Affiliation & Date & Location \\
\hline Aarnio, Ulriikka & ENGO & $9 / 6 / 2015$ & Bonn, Germany \\
\hline Alber, Gotelind & Women and Gender & $13 / 11 / 2013$ & Warsaw, Poland \\
\hline Amerasinghe, Nira & ENGO & $11 / 6 / 2015$ & Bonn, Germany \\
\hline Anderson, Teresa & ENGO & $14 / 11 / 2013$ & Warsaw, Poland \\
\hline Anonymous & BINGO & $05 / 06 / 2013$ & Bonn, Germany \\
\hline Arikan, Yunus & LGMA & $07 / 06 / 2013$ & Bonn, Germany \\
\hline Athanasiou, Tom & ENGO & $10 / 6 / 2015$ & Bonn, Germany \\
\hline Averill, Marylin & RINGO & $06 / 06 / 2013$ & Bonn, Germany \\
\hline Balawag, Grace & IPO & $06 / 06 / 2013$ & Bonn, Germany \\
\hline Black, Barbara & BINGO & $05 / 06 / 2013$ & Bonn, Germany \\
\hline Burgess, Montana & ENGO (CAN) & $12 / 12 / 2014$ & Lima, Peru \\
\hline Cahoon, Kate & Women and Gender & $10 / 6 / 2015$ & Bonn, Germany \\
\hline
\end{tabular}




\begin{tabular}{|c|c|c|c|}
\hline Colley, Peter & TUNGO & $7 / 12 / 2015$ & Paris, France \\
\hline De Coninck, Heleen & RINGO & $09 / 12 / 2014$ & Lima, Peru \\
\hline Drexhage, John & BINGO & $9 / 6 / 2015$ & Bonn, Germany \\
\hline Duyck, Sebastian & CAN (ENGO) & $7 / 12 / 2015$ & Paris, France \\
\hline Endo, Megumi & UNFCCC Secretariat & $08 / 12 / 2+14$ & Lima, Peru \\
\hline Espinoza, Danaé & YOUNGO & $08 / 12 / 2014$ & Lima, Peru \\
\hline $\begin{array}{l}\text { Engelund Friis, } \\
\text { Annette }\end{array}$ & Farmers & $07 / 06 / 2013$ & Bonn, Germany \\
\hline $\begin{array}{l}\text { Engelund Friis, } \\
\text { Annette }\end{array}$ & Farmers & $13 / 11 / 2013$ & Warsaw, Poland \\
\hline Gallehrn, Sebastian & BINGO & $11 / 12 / 2015$ & Paris, France \\
\hline Gracey, Kyle & YOUNGO & $05 / 06 / 2013$ & Bonn, Germany \\
\hline Grant, Jonathan & BINGO & $12 / 12 / 2014$ & Lima, Peru \\
\hline Huq, Saleemul & ENGO & $9 / 6 / 2015$ & Bonn, Germany \\
\hline $\begin{array}{l}\text { Ibrahim, Hindou } \\
\text { Oumarou }\end{array}$ & IPO & $10 / 6 / 2015$ & Bonn, Germany \\
\hline de Jager, Theo & Farmers & $10 / 12 / 2015$ & Paris, France \\
\hline Jintiach, Juan Carlos & IPO & $15 / 11 / 2013$ & Warsaw, Poland \\
\hline Kemp, Luke & YOUNGO & $08 / 06 / 2013$ & Bonn, Germany \\
\hline Kemp, Luke & YOUNGO & $08 / 12 / 2014$ & Lima, Peru \\
\hline Kokorin, Alexey & ENGO & $9 / 6 / 2015$ & Bonn, Germany \\
\hline Mairenal, Dennis & IPO & 08/07/2013 & Bonn, Germany \\
\hline Marquant, Sabrina & YOUNGO & $09 / 12 / 2014$ & Lima, Peru \\
\hline Mendiluci, Maria & BINGO & $5 / 12 / 2015$ & Paris, France \\
\hline Michaelowa, Axel & RINGO & $12 / 11 / 2013$ & Warsaw, Poland \\
\hline Müller, Benito & RINGO & $17 / 6 / 2015$ & Bonn, Germany \\
\hline Murillo, Laura Martin & TUNGO & $15 / 11 / 2013$ & Warsaw, Poland \\
\hline Nair, Usha & Women and Gender & $10 / 12 / 2014$ & Lima, Peru \\
\hline Nair, Usha & Women and Gender & $7 / 12 / 2015$ & Paris, France \\
\hline Nolden, Susanne & LGMA & $10 / 6 / 2015$ & Bonn, Germany \\
\hline Parihar, Gita & ENGO & $15 / 11 / 2013$ & Warsaw, Poland \\
\hline Peters, Jamie & YOUNGO & $12 / 11 / 2013$ & Warsaw, Poland \\
\hline Richards, Julie-Anne & BINGO & $06 / 06 / 2013$ & Bonn, Germany \\
\hline
\end{tabular}




\begin{tabular}{|l|l|l|l|}
\hline Rosemberg, Anabella & TUNGO & $3 / 12 / 2014$ & Lima, Peru \\
\hline Sherpa, Pasang Dolma & IPO & $07 / 06 / 2013$ & Bonn, Germany \\
\hline Sherpa, Lakpa Nuri & IPO & $11 / 12 / 2014$ & Lima, Peru \\
\hline
\end{tabular}

Table 1

\begin{tabular}{|c|c|c|c|c|}
\hline $\begin{array}{l}\text { Type of } \\
\text { Accountability }\end{array}$ & $\begin{array}{l}\text { Accountability } \\
\text { holder }\end{array}$ & $\begin{array}{l}\text { Accountability } \\
\text { wielder }\end{array}$ & $\begin{array}{l}\text { Accountability } \\
\text { standards }\end{array}$ & $\begin{array}{l}\text { Accountability } \\
\text { mechanisms }\end{array}$ \\
\hline $\begin{array}{l}\text { Internal } \\
\text { accountability }\end{array}$ & $\begin{array}{l}\text { Agent in a } \\
\text { principal-agent } \\
\text { relationship }\end{array}$ & $\begin{array}{l}\text { Principal in a } \\
\text { principal-agent } \\
\text { relationship }\end{array}$ & $\begin{array}{l}\text { Standards and } \\
\text { goals agreed } \\
\text { between principal } \\
\text { and agent }\end{array}$ & $\begin{array}{l}\text { Sanctions } \\
\text { agreed } \\
\text { between } \\
\text { principal and } \\
\text { agent }\end{array}$ \\
\hline $\begin{array}{l}\text { External } \\
\text { accountability }\end{array}$ & $\begin{array}{l}\text { Agent exercising } \\
\text { power over } \\
\text { others }\end{array}$ & $\begin{array}{l}\text { Agents affected } \\
\text { by the exercise of } \\
\text { power }\end{array}$ & $\begin{array}{l}\text { Standards of } \\
\text { responsiveness }\end{array}$ & $\begin{array}{l}\text { Mechanisms } \\
\text { to ensure } \\
\text { responsiveness } \\
\text { (voting, }\end{array}$ \\
\hline
\end{tabular}




\begin{tabular}{|c|c|c|c|c|}
\hline & & & & $\begin{array}{l}\text { deliberation, } \\
\text { etc.) }\end{array}$ \\
\hline $\begin{array}{l}\text { Networked } \\
\text { accountability }\end{array}$ & $\begin{array}{l}\text { Agents in a } \\
\text { network }\end{array}$ & $\begin{array}{l}\text { Other agents in } \\
\text { the same network }\end{array}$ & $\begin{array}{l}\text { Standards arise } \\
\text { within the } \\
\text { network }\end{array}$ & $\begin{array}{l}\text { Peer, market, } \\
\text { and } \\
\text { reputational } \\
\text { concerns }\end{array}$ \\
\hline $\begin{array}{l}\text { Institutional } \\
\text { accountability }\end{array}$ & $\begin{array}{l}\text { Agents within a } \\
\text { formal } \\
\text { institutional } \\
\text { space }\end{array}$ & $\begin{array}{l}\text { Other agents } \\
\text { sharing that } \\
\text { institutional space }\end{array}$ & $\begin{array}{l}\text { Standards arise } \\
\text { within the } \\
\text { institutional space }\end{array}$ & $\begin{array}{l}\text { Exit, voice, } \\
\text { and loyalty }\end{array}$ \\
\hline
\end{tabular}

